\title{
In Situ Hybridization pada Kanker Payudara
}

\author{
Witari NPD
}

Fakultas Kedokteran Universitas WARMADEWA, Denpasar-Bali

\begin{abstract}
ABSTRAK
Kesulitan yang dijumpai pada penanganan kanker payudara adalah terjadinya kekambuhan atau relaps. Deteksi status HER2 pada pasien merupakan salah satu upaya untuk mendeteksi terjadinya relaps dan juga untuk menentukan jenis terapi yang ada diberikan. Ekspresi protein HER2 dapat dideteksi dengan immunohistochemistry (IHC), sedangkan mutasi gen HER2 dapat dideteksi dengan teknik in situ hybridization baik berupa fluorescence in situ hybridization (FISH) ataupun chromogenic in situ hybridization (CISH). Metode yang digunakan antara penggunaan CISH maupun FISH serupa. Hal yang membedakan antara keduanya adalah pada CISH pewarnaannya bersifat permanen dan terdapat gambaran back-ground. Kelebihan lain yang diperoleh pada aplikasi CISH adalah reaksi peroksidase yang terjadi dapat divisualisasikan pada mikroskop cahaya.
\end{abstract}

Kata kunci: kanker payudara, HER2, in situ hybridization, CISH, FISH

\begin{abstract}
Difficulties encountered in the treatment of breast cancer is a recurrence or relaps. Detection of HER2 status in patients is an effort to detect relapse and also to determine the type of therapy that is given. HER2 protein expression can be detected by immunohistochemistry (IHC), while the HER2 gene mutation can be detected by in situ hybridization techniques in the form of fluorescence in situ hybridization (FISH) or chromogenic in situ hybridization (CISH). The method used between CISH and FISH is similar. The difference between CISH and FISH occur in permanent coloring and back ground in CISH. Another advantages in CISH is a peroxidase reaction that occurs can be visualized by using light microscope.
\end{abstract}

Keywords : breast cancer, HER2, in situ hybridization, CISH , FISH

\section{PENDAHULUAN}

Kanker payudara adalah tumor yang paling sering di temukan pada wanita di seluruh dunia. Insidensi terjadinya kanker payudara ini terus meningkat mulai tahun 1970. ${ }^{1}$ Kesulitan penanganan kanker payudara terletak pada tingginya angka rekurensi/ relaps. ${ }^{2}$ Salah satu penyebab keadaan ini adalah terjadinya amplifikasi gen HER2. Tingginya amplifikasi gen HER2 pada pasien sering kali juga dikaitkan dengan hasil klinis yang buruk, resistensi terhadap terapi hormon, dan pemberian kemoterapi tipe tertentu 
(certain). Disisi lain terdeteksinya positif HER2 pada pasien merupakan prediktor kuat untuk terjadinya respon terhadap terapi anti-HER2 seperti trustuzumab (herceptin). ${ }^{3}$ Oleh karena pentingnya deteksi status HER2, FDA menyarankan pemeriksaan satatus HER2 pada setiap pasien kanker payudara. $^{4}$

Deteksi HER2 dapat dilakukan dengan berbagai pendekatan seperti pemeriksaan status ekspresi protein HER2 maupun status amplifikasi gen HER2. Pemeriksaan amplifikasi gen HER2 lebih poten dibandingkan dengan pemeriksaan protein HER2 dalam hal diagnosa dini. Hal ini dapat dipahami oleh karena meningkatnya amplifikasi gen akan menginduksi overekspresi gen tersebut. Beberapa tenik imunodeteksi yang sering dilakukan untuk mendeteksi status HER2 antara lain melalui teknik imunohistokimia (IHC) dan juga in situ hybridization (ISH). Teknik IHC dilakukan untuk pemeriksaan ekspresi protein HER2, sedangkan teknik ISH dilakukan untuk pemeriksaan amplifikasi gen HER2. ${ }^{4}$

Teknik ISH memiliki banyak kelebihan dibandingkan dengan IHC terutama dalam sampel pemeriksaan yang digunakan. Walaupun terdapat tahapan antigen retrieval pada sampel jaringan yang ditanam pada blok paraffin di pemeriksaan IHC, namun sensitivitas dan spesifitas imunodeteksinya lebih rendah dibandingkan dengan ISH. Hal ini mengakibatkan seringnya timbul hasil negatif palsu pada sampel pasien kanker payudara yang dideteksi status HER2 dengan menggunakan teknik IHC. ${ }^{4}$

Fluorescence in situ hybridization (FISH) dan chromogenic in situ hybridization (CISH) merupakan salah satu contoh metode ISH yang sering digunakan untuk mendeteksi mutasi gen HER2 pada kanker payudara. ${ }^{5}$ FISH maupun CISH memiliki kelebihan dan kekurangannya masing-masing dalam mendeteksi HER2. FISH memiliki sensitifitas $(96,5 \%)$ dan spesifisitas yang tinggi (100\%) untuk mendeteksi HER2. Visualisasi amplikasi gen di nuklei berbasis sel dengan sel juga dapat teramati secara langsung dengan menggunakan metode FISH. Kekurangan dari metode ini adalah perlunya penggunaan mikroskop fluorescence untuk melakukan pengamatan. Selain itu, pewarnaan fluorescence yang dihasilkan juga bersifat sementara, oleh karena terdapatnya fotobleching. Oleh sebab itu pengamatan harus dilakukan secepatnya setelah pewarnaan. ${ }^{6}$ Berbeda dengan FISH, pewarnaan dengan menggunakan metode 
CISH memberikan lebih banyak berfungsi untuk membuka sekuens DNA keuntungan. Bertolak dari keuntungan target, sedangkan hibridisasi merupakan metode CISH untuk mendeteksi HER2 proses perlekatan antara DNA probe maka penulis ingin mengkaji lebih dalam dengan sekuens DNA target yang mengenai metode CISH pada paper ini. komplementer. Umumnya probe DNA yang

CHROMOGENIC HYBRIDIZATION FLUORESCENCE HYBRIDIZATION (FISH)

Deteksi HER2 dengan menggunakan metode CISH pertama kali dilakukan oleh Turner dan rekan-rekan pada tahun 2000 . Teknik ini dapat diaplikasikan pada sampel kanker payudara yang ditanam pada blok paraffin. Teknik CISH pada awalnya merupakan upaya untuk mengatasi kesulitan keterbatasan prasarana mikroskop fluorescence yang dibutuhkan pada pengamatan akhir teknik FISH. Prinsip dasar deteksi amplifikasi gen HER2 yang digunakan pada penelitian tersebut sama dengan tahapan FISH. Perbedaan teknik CISH terletak pada tahapan akhir, yang menggunakan prinsip enzimatik seperti halnya pada IHC. Oleh karena itu, imunodeteksi pada teknik CISH hanya membutuhkan mikroskop elektron ataupun bright-field microscope. ${ }^{4}$

Tahapan pertama dari metode CISH adalah proses hibridisasi yang diawali dengan denaturasi DNA target. Denaturasi digunakan terlabel dengan digoxigenin.

Deteksi probe dilakukan dengan menggunakan antibodi yang mendeteksi digoxigenin (anti-digoxigenin) dan terlabel flouescence. Flourescence yang sering digunakan sebagai label adalah fluorescein isothiocyanate (FITC). Sampai dengan tahapan ini tidak dijumpai adanya perbedaan antara teknik CISH dan juga FISH (Gambar 1). ${ }^{4}$

Pengamatan hasil akhir pada teknik FISH secara cepat dapat dilakukan setelah imunodeteksi antobodi primer antidigoxigenin yang terlabel dengan fluorescence. ${ }^{4}$ Beberapa hal yang perlu diperhatikan pada saat pengamatan akhir antara lain :

1. Kesesuaian filter mikroskop fluorescence dengan fourescence yang digunakan,

2. Pengamatan harus dilakukan segera setelah pengamatan

3. Sampel irisan jaringan yang telah diwarnai harus disimpan dalam suhu $4^{0} \mathrm{C}$ untuk pengamatan selanjutnya. 
4. Terjadinya bias interobserver pada pemberian antibodi sekunder yang waktu pengamatan yang berbeda.

mengenali fluorescence yang terlabel pada

5. Gambaran morfologi kanker payudara antibodi primer (anti-FITC) dan juga pada sampel perlu di konfirmasi ulang dengan menggunakan pewarnaan rutin terlabel dengan kompleks enzim tertentu. lain (seperti Hematoksilin Eosin).

Kompleks enzim yang biasa digunakan pada tahap ini antara lain horse radish

6. Dibutuhkan observer yang peroxidase (HRP) dan alkali fosfatase. berpengalaman untuk dapat menginterpretasikan hasil akhir pewarnaan dengan teknik FISH.

Berbeda dengan tahapan pada pewarnaan dengan teknik FISH yang berakhir hanya pada penggunaan antibodi primer, tahapan pewarnaan dengan teknik CISH dilanjutkan dengan tahapan reaksi enzimatis. Tahapan ini ditandai dengan Imunodeteksi dilakukan dengan melihat perubahan warna yang terjadi pada sampel setelah pemberian substrat yang sesuai dengan kompleks enzim yang digunakan. Sebagai contoh substrat diamino benzidine (DAB) yang diberikan sebagai kromogen pada penggunaan kompleks enxim peroksidase (HRP) akan memberikan warna kecoklatan (Gambar 2) ${ }^{4}$.

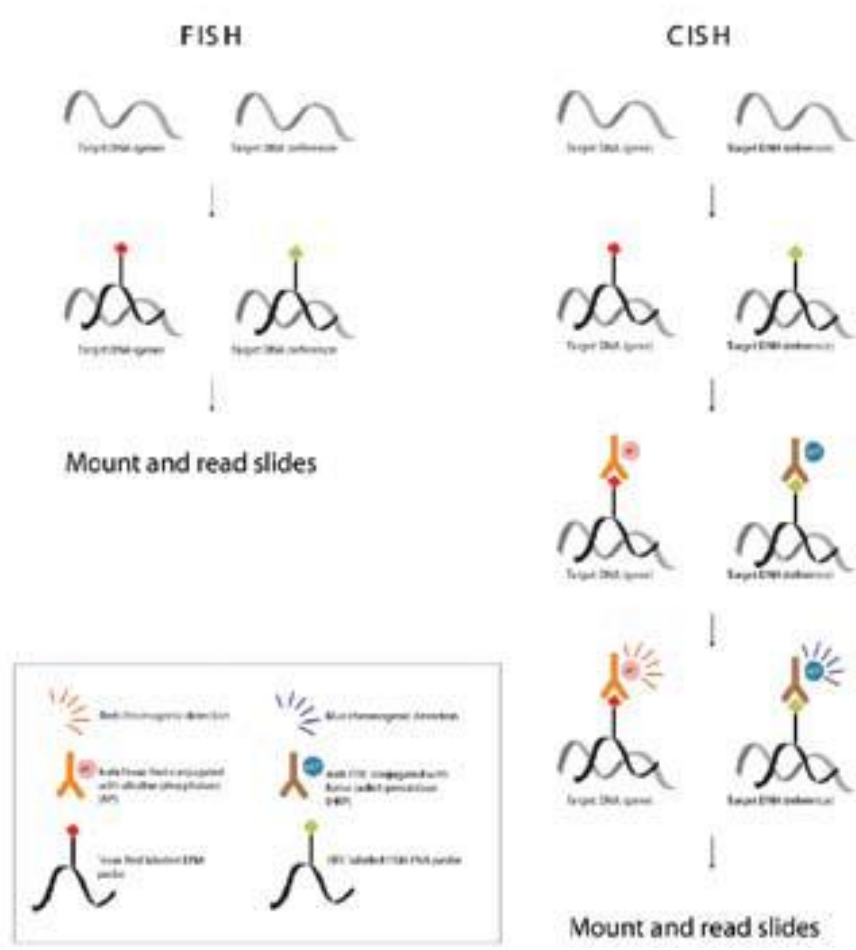

Gambar 1. Tahapan pewarnaan FISH dan CISH. Pewarnaan dengan teknik FISH (sisi kiri gambar) menggunakan antibodi primer terlabel flourescense yang mengenali DNA probe yang terlabel dengan digoxigenin (antibodi anti digoxigenin terlabel fluorescence). ${ }^{6}$ 


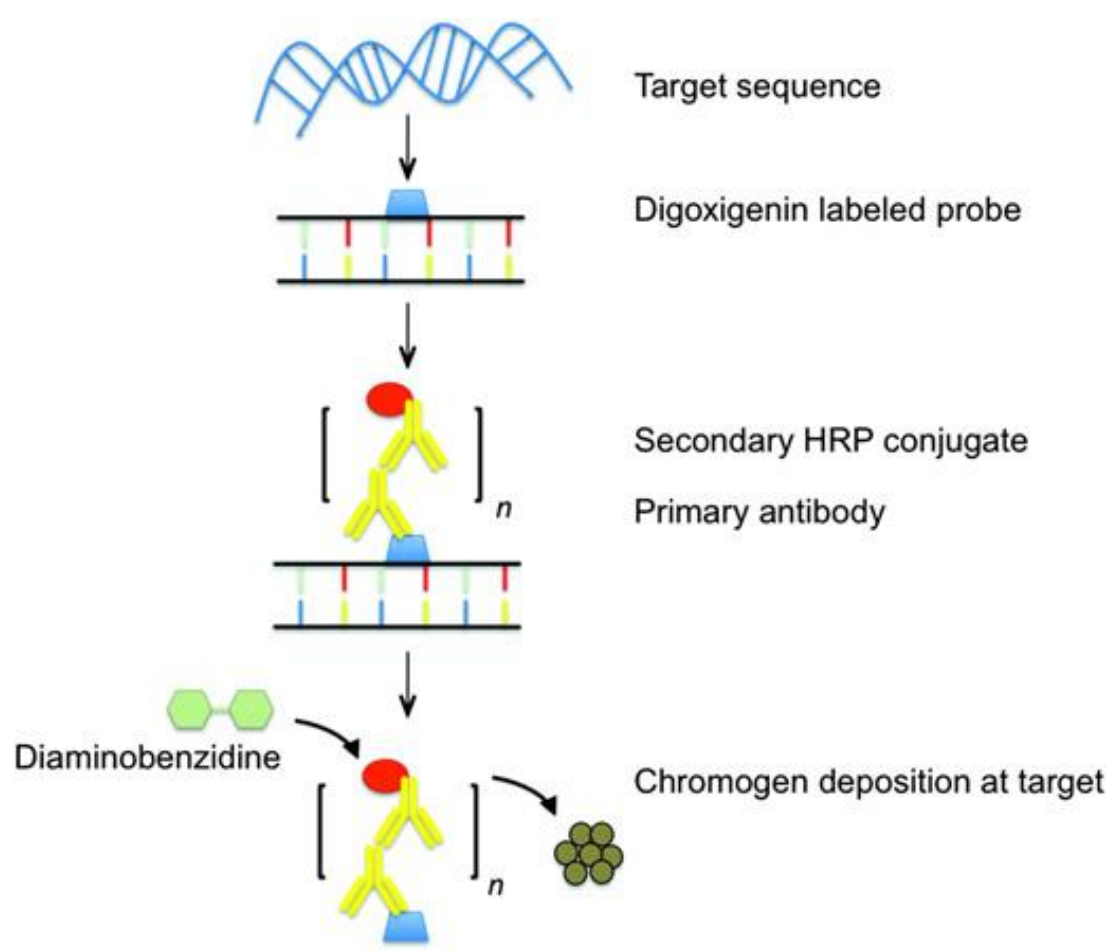

Gambar 2. Skema tahapan metode CISH. Probe terlabel digoxigenin yang melekat pada DNA komplementer dikenali oleh antibodi primer antidigoxigenin. Antibodi sekunder yang terlabel dengan enzim (HRP) akan membentuk kompleks dengan antibodi primer. Pemberian kromogen yang sesuai (pemberian substrat DAB pada kompleks enzim HRP) akan mengakibatkan terjadinya perubahan warna berdasarkan reaksi enzimatis. ${ }^{8}$

Gambaran morfologi dari kanker gambaran morfologis ini memungkinkan payudara pada sampel jaringan pada teknik pengamat untuk dapat mengkonfirmasi CISH dapat dilihat dengan mengaplikasikan lokasi intraseluler gambaran imunopositif pewarnaan rutin sederhana sebagai pada pewarnaan CISH, serta gambaran counterstaining pada tahap akhir. histologis jaringan kanker payudara pada Kemampuan untuk memproyeksikan preparat yang sama. Hasil akhir pewarnaan

Tabel 1. Tabel interpretasi hasil pemeriksaan imunodeteksi pewarnaan in situ hybridization (CISH dan FISH). ${ }^{4}$

\begin{tabular}{|c|c|}
\hline interpretasi hasil & gambaran imunodeteksi \\
\hline Tidak terjadi amplifikasi gen HER2 & $\begin{array}{l}\text { 1-5 kopi gen HER2 di tiap nukleus pada lebih dari } 50 \% \\
\text { sel kanker. }\end{array}$ \\
\hline Terjadi amplifikasi gen HER2 & $\begin{array}{l}\text { lebih dari } 6 \text { kopi gen HER2 ataupun terdapat gambaran } \\
\text { kluster di tiap nukleus pada lebih dari } 50 \% \text { sel kanker }\end{array}$ \\
\hline a. Amplifikasi rendah & $\begin{array}{l}\text { 6-10 kopi gen HER2 ataupun terdapat gambaran kluster } \\
\text { kecil di tiap nukleus pada lebih dari } 50 \% \text { sel kanker }\end{array}$ \\
\hline b. Amplifikasi tinggi & $\begin{array}{l}>10 \text { kopi gen HER } 2 \text { ataupun terdapat gambaran kluster } \\
\text { besar di tiap nukleus pada lebih dari } 50 \% \text { sel kanker }\end{array}$ \\
\hline
\end{tabular}


CISH bersifat permanen dan tidak Perbedaan yang tampak jelas dari kedua membutuhkan suhu khusus untuk teknik ini adalah bahwa teknik FISH dapat mempertahankan hasil akhir pewarnaan. digunakan sebagai alat diagnose cepat atau Bias interpretasi akhir antar observer pada untuk skrining deteksi amplifikasi gen teknik CISH dapat diminimalisir oleh dibandingkan dengan teknik CISH. Hal ini karena sifat pewarnaan yang permanen ini. dapat dimengerti oleh karena tahapan yang Kemudahan lainnya pada teknik CISH dilalui pada pewarnaan dengan adalah pengamatan dapat dilakukan dengan menggunakan teknik FISH jauh lebih menggunakan mikroskop sederhana yang singkat dibandingkan dengan CISH. Namun rutin dimiliki pada tiap laboratorium. ${ }^{4}$ untuk penelitian jangka panjang

INTERPRETASI AMPLIFIKASI GEN HER2 PADA CISH DAN FISH

Interpretasi terjadinya amplifikasi gen HER2 pada teknik CISH dan FISH pada sampel jaringan kanker payudara serupa (Tabel 1 dan Gambar 2). ${ }^{4}$

\section{APLIKASI PENGGUNAAN CISH DAN FISH}

Baik CISH maupun FISH sensitif untuk mengetahui terjadinya amplifikasi gen HER2 pada penyakit kanker payudara.

$$
\text { penggunaan teknik CISH lebih disukai oleh }
$$

karena sifat pewarnaannya yang tidak mudah berubah (permanen). ${ }^{4-8}$

Sensitivitas maupun spesifitas diagnosa status HER2 dengan menggunakan teknik CISH maupun FISH relatif tinggi. Zhao et al. mengatakan bahwa dengan menggunakan teknik CISH ataupun FISH mampu mendeteksi status HER2 pasien yang sebelum nya telah diperiksa dengan teknik IHC menunjukkan hasil negatif. Dalam suatu penelitian yang
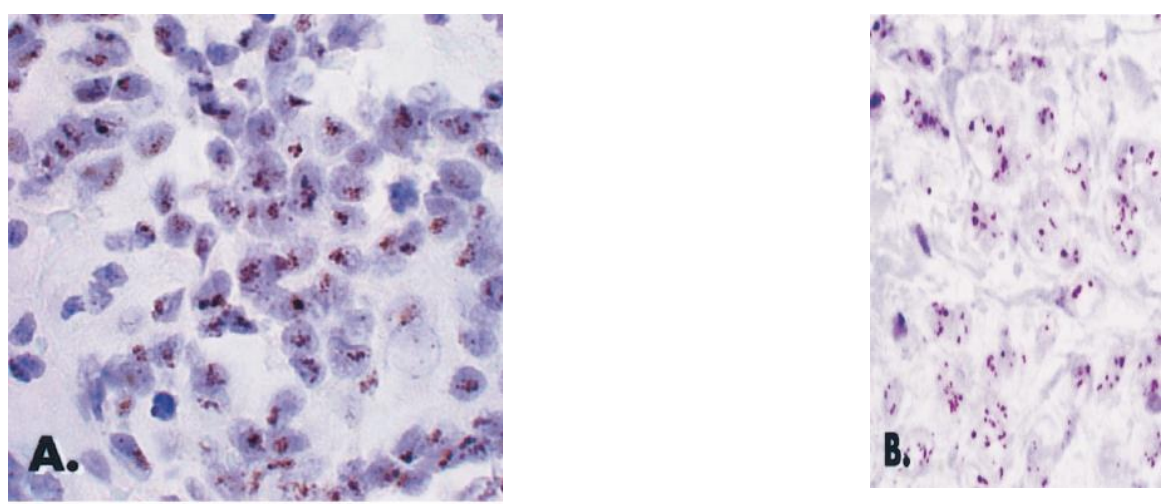

Gambar 2. Gambaran amplifikasi gen HER2 pada kanker payudara manusia dengan pewarnaan CISH yang di counterstain dengan hematoxilin. Gambaran imunopositif peroksidase kopi gen HER2 pada inti sel kanker (panah hitam) dengan gambaran kluster (Gambar A) dan gambaran individual kopi gen (gambar B). Gambar perbesaran 400x. ${ }^{4}$ 
lain dikatakan bahwa bahwa sensitivitas CISH lebih rendah dibandingkan dengan FISH. Oleh karena alasan tersebut, jika hasil pemeriksaan degan menggunakan CISH menunjukkan hasil yang negatif perlu dikonfirmasi ulang dengan menggunakan FISH. Namun melihat kelebihan yang ada dengan menggunakan pewarnaan dengan teknik CISH, terbuka potensi luas untuk mempergunakan metode ini sebagai suatu metode alternatif/ opsional dalam deteksi dini rekurensi terjadinya kanker payudara. Pengembangan lebih lanjut dibutuhkan untuk lebih meningkatkan sensitivitas maupun spesifitas deteksi status HER2 dengan menggunakan $\mathrm{CISH}^{4-8}$

\section{KESIMPULAN}

Deteksi status HER2 berdasarkan amplifikasi gen dengan teknik CISH maupun FISH lebih poten untuk mendiagnosa rekurensi penyakit kanker payudara dibandingkan dengan teknik IHC. Sensitivitas deteksi amplifikasi gen HER2 dengan teknik FISH lebih tinggi dibandingkan degan CISH. Kelebihan dari pewarnaan CISH yang bersifat permanen, mampu melihat gambaran morfologis kanker serta dan mampu diaplikasikan pada fasilitas laboratorium rutin yang ada, membuat teknik ini lebih menjanjikan untuk dapat mendiagnose status amplifikasi gen HER2 pada penyakit kanker payudara.

\section{DAFTAR PUSTAKA}

1. Belki O, Hall P, Ekbom A, Moradi T. Breast Cancer Insidence and Case Fatality among 4,7 Milion Woman in Relation to Social and Ethnic Backround: a populationbase Cohort Study. Breast Cancer Res Tr. 2012. 14: R5.

2. Bartlett JM, Campbell FM, Ibrahim M, Wencyk P, Ellis I, Kay E, et al. Chromogenic In Situ Hybridization. Am J Clin Pathol. 2009. 132: 514-520.

3. Gong Y, Sweet W, Duh YJ, Greenfield L, Fang Y, Zhao J, et al. Chromogenic In Situ Hybridization is a Reliable Method for Detecting HER2 Gen Status in Breast Cancer. a multicenter study using conventional scoring criteria and the new ASCO/CAP recommendations. Am J Clin Pathol. 2009. 131: 490-497.

4. Zhao J, Wu R, Au A, Marquez, A., Yu, Y., Shi, Z. Determination of HER2 gene amplification by chromogenic in situ hybridization (CISH) in archival breast carcinoma. Modern Pathol. 2002. 15(6): 657.

5. Rosa FE, Santos RM, Rogatto SR, Domingues MAC. Chromogenic In Situ Hybridization Compared With Other Approaches to Evaluate HER2/Nneu Status in Breast Carcinomas. Braz $\mathrm{J}$ Med Biol Res. 2013. 46: 207-216.

6. Gupta D, Middleton LP, Whitaker MJ, Abrams J. Comparation of Flourescence and Chromogenic In Situ Hybridization for Detection of HER-2/neu Oncogene in Breast Cancer. Am J Clin Pathol. 2003. 119: 381-387.

7. Arnould L, Denoux Y, MacGrogan G, Penault-Llorca F, Fiche M, Treilleux I, et al. Agreement Between Chromogenic In Situ Hibridisation (CISH) and FISH in The Determination of HETR2 Status in Breast Cancer. Brit J Cancer. 2011. 88: 15871591. 
8. Gruver AM, Peerwani Z, Tubbs RR. Out of Darkness and Into the Light: Bright Field In Situ Hybridization for Delineation of
ERBB2 (HER2) status in Breast Carcinoma. J clin pathol. 2010. 63: 210219. 